\title{
VOCATIONAL TEACHERS' OPINIONS ABOUT THE ALREADY ACQUIRED AND YET TO BE IMPROVED COMPETENCES IN THE CONTEXT OF THE FOURTH INDUSTRIAL REVOLUTION
}

\author{
Nijolė Bankauskienė \\ Kaunas District Akademija Ugnes Karvelis Gymnasium, Lithuania \\ Ramunè Masaitytè \\ Kaunas Technical Vocational Education Center; Kauno Kolegija/ \\ University of Applied Sciences, Lithuania
}

Alicija Ramanauskaitè

King Mindaugas Vocational Training Center, Lithuania

\begin{abstract}
The fourth industrial revolution is associated with the ever-increasing requirements for vocational training. The important factors that are required for the qualitative change of vocational training include increasing the diversity of the vocational training programs, optimization of the school network, increasing the effectiveness and interaction between primary vocational training and the training systems of the labor market, and effective improvement of the qualification/competences of vocational teachers. The understanding of the changing role of vocational teachers and the expression of their competences are directly related to the learning motivation, self-education, striving for continuous education, and orientation towards the improvement of the acquired professional qualification among the learners of vocational training centers. This paper presents theoretical insights into the vocational teachers' competences, comparing the documents that regulate European and Lithuanian vocational training, and presents the results of the interview of a focus group with vocational teachers of Kaunas city vocational training centers. The qualitative study aimed at revealing which competences were expressed among vocational teachers in the context of the fourth industrial revolution. The study showed that the vocational teachers regarded the group of functional (activity) competences as most important for the quality of their work and recognized the influence of the fourth industrial revolution on changes in their competences. Keywords: vocational teacher, competence, fourth industrial revolution.
\end{abstract}

\section{Introduction}

As the fourth industrial revolution is gaining momentum, the requirements for specialists -professionals are ever increasing, requiring continuous development of their qualification and competences. 
Bankauskiene et al., 2020. Vocational Teachers' Opinions about the Already Acquired and Yet to be Improved Competences in the Context of the Fourth Industrial Revolution

Schwab (2017) stated that the challenges of the fourth industrial revolution (Industry 4.0) may only be overcome with the help of Education 4.0 (education 4.0 is understood as the teaching/learning process in the digital age). Education will have to adapt, to introduce radical changes in its educational content, to organize the educational process in the modern way, and to develop the abilities that correspond to the global development trends. Education 4.0 is a plan of lifelong learning - from childhood to the workplace (Fisk, 2017). The main principles of Education 4.0 are individual work and teamwork, creation in all stages of work, continuous personality development, and cooperation with social partners in accordance with the value-based principles (Harkins, 2008). The greatest challenges that are faced by modern business (and especially production) enterprises are a lack of workers and an increase in work efficiency determined by the $21^{\text {st }}$-century activity competences (Boyatzis \& Boyatzis, 2008, Binklley, Erstad, Herman, Raizen et al., 2012).

Changes in the economy and the associated necessity not only to provide newly trained workers to the labor market, but also to create conditions for continuous updating of the workers' qualification are the challenges that vocational training institutions are facing today because vocational trainings the area where the future of the labor world is forming.

As global practice indicates (CEDEFOP, 2001-2018), important factors that are required for the qualitative change of vocational training include increasing the diversity of the vocational training programs, optimization of the school network, increasing the effectiveness and interaction between primary vocational training and the training systems of the labor market, and effective improvement of the qualification/competences of vocational teachers. Special emphasis is placed on vocational teachers' personal characteristics, motivation, an innovative approach to their activity, and willingness to improve continually through the adoption of the good experience in vocational training (Daukilas, Mičiulienè, Kovalčikienè et al., 2016). The understanding of the changing role of vocational teachers and the expression of their competences are directly related to the learning motivation, self-education, striving for continuous education, and orientation towards the improvement of the acquired professional qualification among the learners of vocational training institutions.

The object of this study was vocational teachers' competences.

The aim of the study was to reveal which competences were expressed among vocational teachers of Kaunas city vocational training centers in the context of the fourth industrial revolution. To achieve this aim, we 1) presented theoretical insights into the vocational teachers' competences, comparing the documents that regulate European and Lithuanian vocational training, and presented the results of the interview of the focus group with vocational teachers of Kaunas city vocational training centers; 2) we analyzed Kaunas city 
vocational teachers' opinions about the already acquired and yet to be improved competences in the context of the fourth industrial revolution.

\section{Vocational teachers' competences}

Education 4.0 is directly related to the quality of vocational teachers' activity because the teachers are involved in the training of highly qualified future workers. The competences demonstrated by vocational teachers and the way the teachers implement their activities and perform their roles as educators will significantly influence their learners' - future professionals' readiness to confront the challenges of the fourth industrial revolution.

In this article we propose definition of teacher competence based on the analysis of the most widely referenced definitions of competence. When analyzing the Common European Principles for Teacher Competences and Qualifications published in 2005 by the European Commission, Caena (2011) noted the provision that a teacher should be capable of effectively working in all three overlapping fields of activity:

1. work with information, technologies, and knowledge;

2. work with people (learners, colleagues, and other partners); and

3. work with the society and in the society on the local, regional, national, European, and global levels.

The document emphasizes four important competence groups that the pedagogues should have:

- Cognitive competences involving the use of theory and concepts, as well as informal presumed experience-based knowledge;

- $\quad$ Functional competences involving skills and technical knowledge, i.e. the things that individuals should be capable of doing when acting in a certain field of work, learning, or social activity;

- Personal competences - i.e. knowing how to behave in a certain situation;

- $\quad$ Ethical competences - i.e. the expression of certain personal and professional values.

These competences described in the aforementioned document of the European Commission are in line with the competences of Lithuanian pedagogues highlighted in the Description of Teachers' Professional Competences approved by the Order of the Minister of Education and Science of the Republic of Lithuania No. ISAK - 54 on January 15, 2007. It highlights overall cultural, professional, and general competences. The compatibility of these two competence groups has been analyzed in various aspects by Bankauskienè and Masaitytė (2018, 2019), Kunter, Klusmann, Baumert, Richter, Voss, Hachfeld, (2013), Oluwasola (2014), Grollmann (2008) and other. 
Bankauskiene et al., 2020. Vocational Teachers' Opinions about the Already Acquired and Yet to be Improved Competences in the Context of the Fourth Industrial Revolution

In order to emphasize the quality of vocational teachers' activity, specific documents related to the teachers' roles in the education process have been adopted.

The Regulations of Vocational Teachers' Qualification Improvement approved by the Order of the Minister of Education and Science of the Republic of Lithuania No. ISAK -591 on April 3, 2007 emphasized vocational teachers' professional, overall cultural, general, and special competences.

On August 29, 2014, the Description of the Requirements of Teachers' Qualification was approved by the Order of the Minister of Education and Science of the Republic of Lithuania No. V-774. This document sets qualifications necessary for teachers working in vocational training programs.

Another document that is important for the activity of a vocational teacher is the Methods of the Description of the Positions of Teachers (Except for Coaches) (Ministry of Education and Science of the Republic of Lithuania, Order No. V-674, July 26, 2018). This document emphasizes the following abilities: digital literacy, the Lithuanian language, foreign languages, and three groups of a teacher's functions that require a vocational teacher's competence:

Functions for the implementation of the (...) vocational training (...) educational program according to the hours set in the education (teaching) plans;

Functions for the preparation for the implementation of the programs: planning of the educational activity, preparation for classes, evaluation of the learners' achievements, informing the learners and their parents about the learners' educational and self-education needs and the learning progress, and professional development;

Functions related to the activity for the benefit of the school community, other educational activity with the learners, cooperation (...) with the group, (....) coordination or preventive programs, and other activities.

An even more detailed description of vocational teachers' activities and competences was presented in the Professional Standard of the Activity of the Education Sector and Libraries approved on July 19, 2019. This document describes 18 competences of a vocational teacher in 6 areas of activity corresponding to the main functions of a vocational teacher:

Planning of the content and the process of vocational training;

Theoretical and practical vocational training;

Evaluation of the learners' achievements and progress;

Professional information and consulting;

Continuous professional development;

Activity for the benefit of the school community. 
Table 1 Associations between the Common European Principles for Teacher Competences and Qualifications and Lithuanian normative documents on vocational training with respect to vocational teachers' competences

\begin{tabular}{|c|c|c|c|}
\hline \multirow[b]{2}{*}{$\begin{array}{c}\text { Common } \\
\text { European } \\
\text { Principles for } \\
\text { Teacher } \\
\text { Competences } \\
\text { and } \\
\text { Qualifications } \\
\text { (2005) }\end{array}$} & \multicolumn{3}{|c|}{ Lithuanian normative documents on vocational education and training } \\
\hline & $\begin{array}{c}\text { Competences of the } \\
\text { Description of Teachers' } \\
\text { Professional Competences } \\
\text { (2007) }\end{array}$ & $\begin{array}{l}\text { Vocational teachers' } \\
\text { competences according } \\
\text { to the Methods of the } \\
\text { Description of the } \\
\text { Positions of Teachers } \\
\text { (2018) }\end{array}$ & \begin{tabular}{|} 
Vocational teachers' \\
competence groups \\
according to the \\
Professional Standard of \\
the Activity of the \\
Education Sector and \\
Libraries \\
(2019)
\end{tabular} \\
\hline $\begin{array}{l}\text { Cognitive } \\
\text { competences }\end{array}$ & $\begin{array}{l}\text { - communication and } \\
\text { information management; } \\
\text { - research activity; } \\
\text { - reflection and learning to } \\
\text { learn. }\end{array}$ & $\begin{array}{l}\text { - knowledge of the } \\
\text { Lithuanian and foreign } \\
\text { languages; } \\
\text { - professional } \\
\text { development. }\end{array}$ & $\begin{array}{l}\text { - planning of the content } \\
\text { and the process of } \\
\text { vocational training. }\end{array}$ \\
\hline $\begin{array}{l}\text { Functional } \\
\text { competences }\end{array}$ & $\begin{array}{l}\text { - information technology } \\
\text { use; } \\
\text { - organization improve- } \\
\text { ment and change } \\
\text { management; } \\
\text { - planning and impro- } \\
\text { vement of the subject } \\
\text { content; } \\
\text { - creation of educational } \\
\text { environments; } \\
\text { - management of the } \\
\text { teaching/ learning process; } \\
\text { - evaluation of learners' } \\
\text { achievements and progress. }\end{array}$ & $\begin{array}{l}\text { - digital literacy skills; } \\
\text { - activity in the school } \\
\text { community; } \\
\text { - planning of the } \\
\text { educational activity; } \\
\text { - preparation for classes; } \\
\text { - carrying out vocational } \\
\text { training; } \\
\text { - evaluation of learners' } \\
\text { achievements. }\end{array}$ & $\begin{array}{l}\text { - theoretical and practi- } \\
\text { cal vocational training; } \\
\text { - professional informa- } \\
\text { tion and consulting; } \\
\text { - activity for the benefit } \\
\text { of the school } \\
\text { community. }\end{array}$ \\
\hline $\begin{array}{l}\text { Personal } \\
\text { competences }\end{array}$ & $\begin{array}{l}\text { - knowing the learners; } \\
\text { - communication and } \\
\text { cooperation; } \\
\text { - professional development; } \\
\text { - intercultural competence. }\end{array}$ & $\begin{array}{l}\text { - identification of } \\
\text { learners' educational } \\
\text { needs; } \\
\text { - cooperation with } \\
\text { learners' parents and } \\
\text { colleagues; } \\
\text { - professional } \\
\text { development; } \\
\text { - group management, } \\
\text { coordination of various } \\
\text { projects. }\end{array}$ & $\begin{array}{l}\text { - Continuous } \\
\text { professional } \\
\text { development. }\end{array}$ \\
\hline $\begin{array}{l}\text { Ethical } \\
\text { competences }\end{array}$ & $\begin{array}{l}\text { - learners' motivation and } \\
\text { support; } \\
\text { - recognition of the } \\
\text { learners' progress. }\end{array}$ & $\begin{array}{l}\text { - communication and } \\
\text { cooperation with the } \\
\text { learners; } \\
\text { - recognition of the } \\
\text { learners' progress. }\end{array}$ & $\begin{array}{l}\text { - evaluation of the } \\
\text { learners' achievements } \\
\text { and progress. }\end{array}$ \\
\hline
\end{tabular}


Bankauskiene et al., 2020. Vocational Teachers' Opinions about the Already Acquired and Yet to be Improved Competences in the Context of the Fourth Industrial Revolution

The competences of vocational teachers described in normative documents of the Republic of Lithuania on vocational training show associations with the aforementioned competences defined by the European Commission (2005) and the overall cultural, professional, general, and special competences that are not explicitly indicated there (See Table 1).

In general, it can be stated that the Lithuanian normative documents that regulate vocational training and define the competences of vocational teachers are in line with the EU normative documents identifying groups of cognitive, functional, personal, and ethical competences.

\section{Methods of the study}

The empirical study was carried out from December 2019 to January 2020. We conducted a qualitative limited-scope study by applying a focus group interview and qualitative content analysis. Based on the analysis of European and Lithuanian normative documents on vocational training, we constructed an interview containing open-ended questions. The empirical focus group interview was carried out as a round-table discussion. The studied group was formed by applying the criterion-based selection technique according to the following criteria: current work in the profession and at least 3 years of working experience in the profession and in different vocational training programs. The study was based on the provision that studies of vocational teachers' opinions and evaluations are important because not only do they allow for analyzing the expression of the vocational teachers' competences, but they also are important for the improvement of vocational teachers' education and training as well as for the planning of their qualification improvement directions. Concerning the methodological approach, this is a qualitative study (Marshall \& Rossman, 2011).

The focus group study involved 10 vocational teachers (experts), of which 9 were females, and 1 was male. Their work experience ranged from 3 to 40 years. The participants' verbal consent was obtained prior to the interview. The interview was recorded with an audio recorder. The transcribed text was saved as a document, which, according to the time of the creation (the interview was recent) and the authorship (the authors of the record are members of the focus group study), the document may be regarded as a primary source. The document was then analyzed by applying content analysis. The participants of the study were assigned identification codes. The data of the study were grouped by forming categories and subcategories to which the participants' statements were assigned.

During the study, continuous validity assurance was applied. In this study, internal validity was ensured by the following measures: the use of a recorder, 
the involvement of the investigators in data collection, transcription, and analysis, and the application of the data filtering mechanism.

The interview consisted of five questions:

- What competences should a vocational teacher have?

- What competences are most important for your work as a vocational teacher?

- $\quad$ Are the competences that a vocational teacher should have changing as a result of the realities of the fourth industrial revolution?

- $\quad$ Are the competences that a vocational teacher should have changing due to contacts with modern learners (the "Z" and the " 0 " generations, etc.)?

- Which competences do you think you need to acquire/improve?

The study participants were assigned identification codes (PM1, ....., PM10). The data of the study were grouped by forming categories and subcategories to which the participants' statements were assigned.

\section{Expression of vocational teachers’ activity competences}

The analysis of the data obtained during the focus group interview allowed for defining five categories based on the open-ended questions presented to the study participants during the interview:

1. The importance of competences for the quality of avocational teacher's work;

2. The competences that are most important for the studied vocational teachers' work;

3. The changes in the competences that a vocational teacher should have as a result of the realities of the fourth industrial revolution;

4. The competences that a vocational teacher should have with respect to the modern learners;

5. The competences that should be acquired/improved.

We identified subcategories that corresponded to the competence groups presented in the EC document Common European Principles for Teacher Competences and Qualifications.

1. The studied vocational teachers identified competences important for the quality of avocational teacher's activity (Fig. 1). 
Bankauskiene et al., 2020. Vocational Teachers' Opinions about the Already Acquired and Yet to be Improved Competences in the Context of the Fourth Industrial Revolution

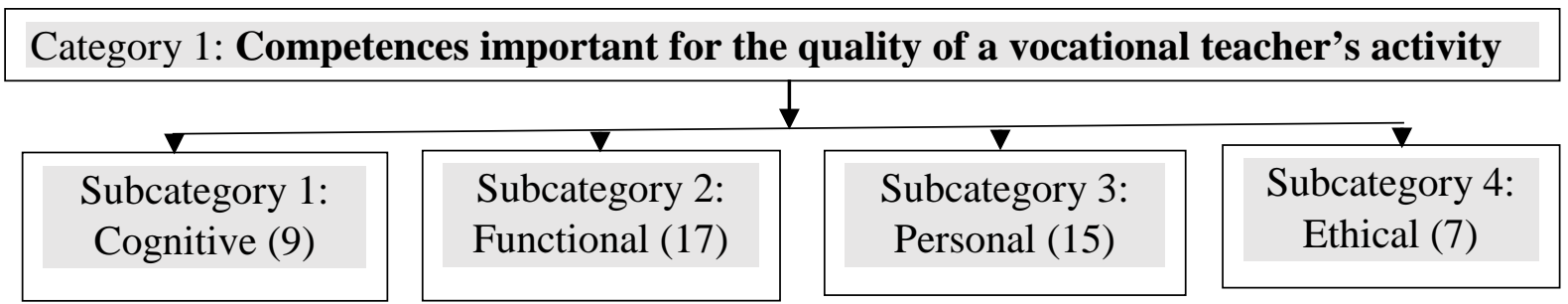

Figure 1 Subcategories of the category "Competences important for the quality of a vocational teacher's activity", and the number of the supporting statements

This was also illustrated by the vocational teachers' statements in the focus group study:

"A vocational teacher is a person who has both theoretical and practical knowledge. It is important to be capable of conveying theoretical knowledge through practical assignments. The presentation of theoretical material should be oriented towards the analysis of the practical experience of the subject taught, creating realistic situations. The teacher's ability to learn and to improve his or her knowledge in the context of the subject taught is important here, as is the ability to evaluate critically the novelties and to apply them when conveying knowledge to the learners. Also of importance are general competences such as the ability to work with a computer and communication and cooperation skills when working with learners and colleagues" (PM1).

"A vocational teacher should know his or her work well, should be able to communicate with learners of different ages and abilities, should know the modern technologies, and should have general competences" (PM5).

When identifying competences that vocational teachers should have, members of the focus group mentioned technological (subject/vocational training program), pedagogical (creation of learning/teaching environments, content planning, management of the learning/teaching process, evaluation of learners' achievements, etc.), personal (learning and improving one's knowledge), and general competences (communication, cooperation, IT use, and overall cultural competence):

"First of all, a vocational teacher has to be a specialist in the field and should know his or her subject well. Of course, all the professional competences of a teacher are of equal importance: the use of information technologies, planning and improvement of the subject content, evaluation of the learners' achievements and progress, professional development, etc." (PM2).

Most frequently, the respondents mentioned competences attributed to the functional subcategory (17 statements), while competences of the ethical subcategory were mentioned least frequently (7statements).

2. The participants of the study were vocational teachers who were teaching professions in the areas of personal services and engineering. When identifying competences that were most important for a vocational teacher's 
work, the respondents noted that of importance were the majority of the competences characteristic of general education teachers:

"The most important competences that I would identify include selection of the learning material that would be interesting to the learners, management of the learning process, management of conflicts or discords, modern technology use, and application of different teaching and learning techniques. Stimulation of the learners' creativity and critical thinking is also of utmost importance." (PM6).

"In addition to the theoretical and practical knowledge of the taught subject, communication skills are also important, as they help to involve the learner into the learning process. A teacher's communication skills help to arouse the learner's interest not only in the subject taught, but also in the teacher's personal characteristics, which forms a positive opinion about both the teacher's profession and the learner's future profession. The public speaking competence helps manage the audience and maintain attention. Computer literacy is important for conveying the material in an interactive and attractive manner. A teacher's ability to evaluate and encourage a learner's personal characteristics motivates the learner for striving to achieve the aims, for selfimprovement, and for self-realization.” (PM1).

"Work in a class involves great responsibility, creativity, cooperation and communication, working skill formation, technological novelties, and valuebased attitudes." (PM9).

The teachers did not speak about concrete competences that were important for a subject/profession and were attributed to the functional competence subcategory, grouping them as "professional" or "technological" competences. Most frequently, the teachers mentioned competences of the functional subcategory (13 statements), and did not mention competences of the cognitive subcategory (Fig. 2).

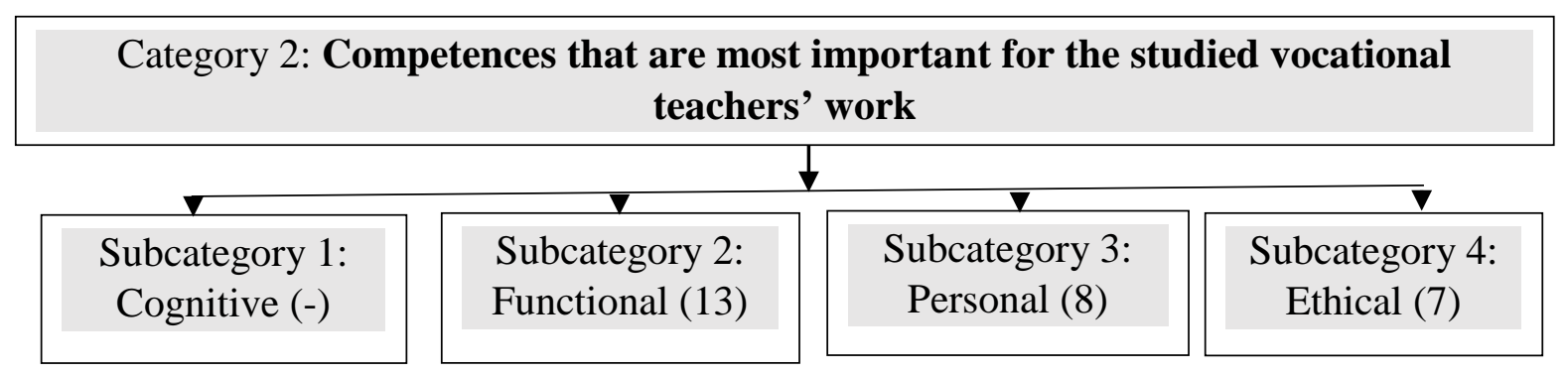

Figure 2 Subcategories of the category "Competences that are most important for the studied vocational teachers' work", and the number of the supporting statements

3. The third category was called Changes in the competences that a vocational teacher should have as a result of the realities of the fourth industrial revolution. All the teachers who participated in the study recognized the need for changes in vocational teachers' competences (Fig. 3). Digitalization 
Bankauskiene et al., 2020. Vocational Teachers' Opinions about the Already Acquired and Yet to be Improved Competences in the Context of the Fourth Industrial Revolution

of the industry was the most frequently mentioned cause of changes in vocational teachers' competences:

"Yes, there are significant changes. As digitalization is increasing and new technologies are emerging, vocational teachers' competences have to change as well" (PM8).

"There are changes. The use of information technologies is important when applying knowledge. Theoretical material may be used in video or audio format, replacing or supplementing the usual articles or books. Learners prefer listening to or watching lectures to reading articles or slides. Communication with the learners became accessible and fast. The most recent news is rapidly spread with five-minute accuracy. Provision of information in the taught subject or enhancement of professional knowledge may be carried out via simple cooperation or correspondence, by sharing information via social networks or via e-mail. However, the industrial revolution has negative consequences as well: the continuous use of information technologies reduces the learners' interest and ability to concentrate. Their attention is "jumping" all the time. Continuous communication with friends sometimes becomes more important than the topic of the class, and thus the learners are not always capable of arranging their time properly." (PM1).

Vocational teachers noted that the fourth industrial revolution encouraged teachers to become more interested in technologies and to improve their IT competences.

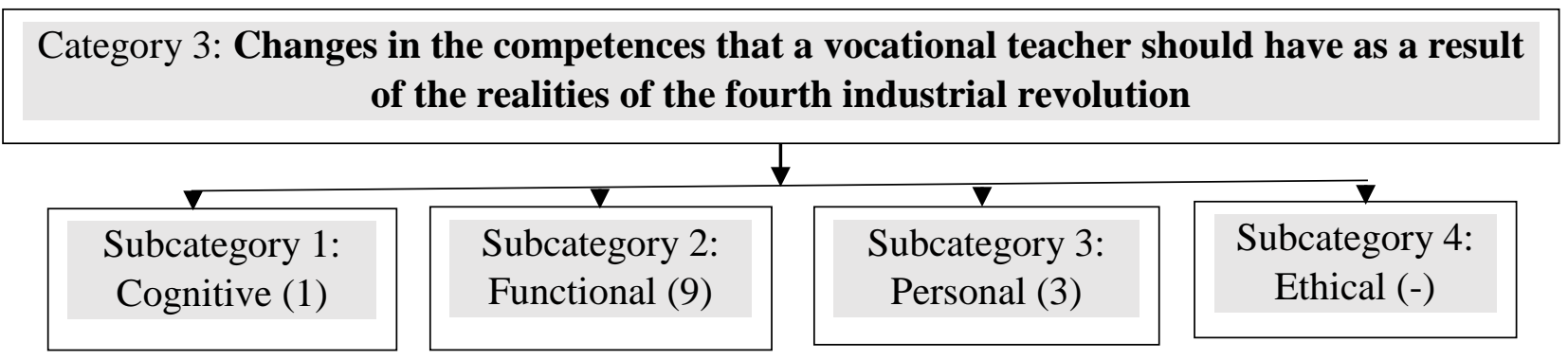

Figure 3 Subcategories of the category "Changes in the competences that a vocational teacher should have as a result of the realities of the fourth industrial revolution", and the number of the supporting statements

In this category, vocational teachers most frequently mentioned competences in the functional subcategory (9 statements), while none of the respondents mentioned any competences in the ethical subcategory.

4. In the category Competences that a vocational teacher should have with respect to the modern learners (generations " $Z$ " and " 0 "), the vocational teachers expressed their attitudes towards changes (Fig. 4):

"Yes, there are changes because the learners themselves are changing because of the extensive IT information stream" (PM10). 
"Yes. A teacher should be dynamic, fast orienting, and interested in novelties. A teacher should use social networks, applications, and, if possible, should include smartphone and computer use into the learning process. Psychological knowledge about learners of a certain age and their behavior is also highly important." (PM2).

However, some vocational teachers who participated in the study did not see such changes:

„The competences do not change, simple more novelties that are important for the presentation of the material emerge. A teacher should continuously learn and improve his or her knowledge and skills." (PM6).

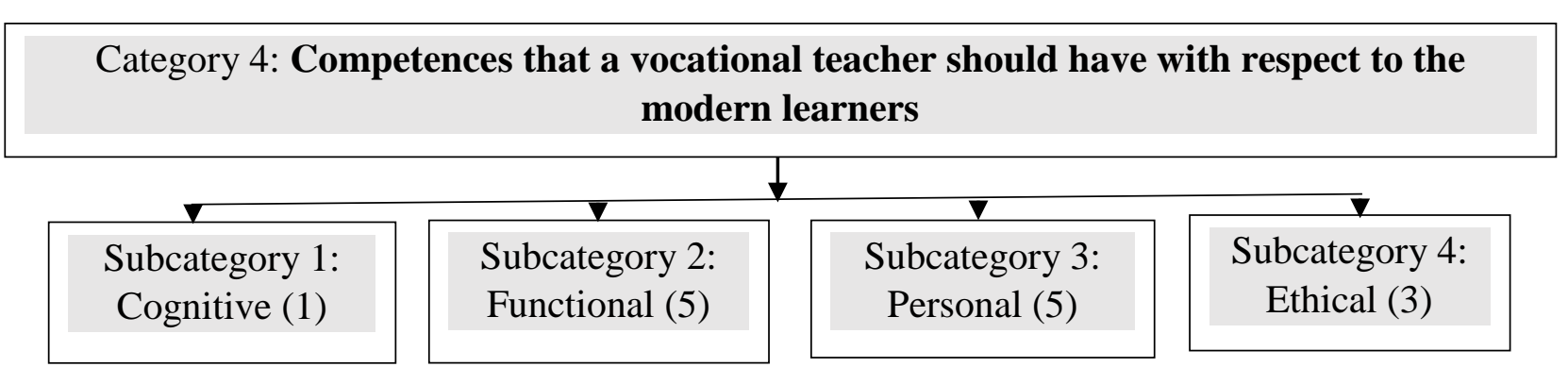

Figure 4 Subcategories of the category "Competences that a vocational teacher should have with respect to the modern learners", and the number of the supporting statements

The respondents most frequently mentioned competences in the functional and personal subcategories (5statements each), while competences in the cognitive subcategory were mentioned least frequently (1 statement).

5. Competences that should be acquired/improved. This category of competencies attracted all participants' attention and comments. Vocational teachers understand that lifelong learning is a necessity, as are updating of the current competences and acquisition of new ones (Fig. 5):

"The newest trends in information technologies during classes, continuous improvement of the communication and cooperation skills, and updating of professional knowledge." (PM1).

"I think that the competence of information technology use should be improved all the time. In addition, the competence of the use of new teaching and learning methods should be acquired or improved." (PM2).

"Professional competences, subject-based competences, and improvement of psychological and communication competences." (PM4).

The analysis of the interview with vocational teachers showed that in this category, the most frequently mentioned competences were those of the functional subcategory (9 statements), while competences of the cognitive subcategory were mentioned least frequently (1 statement). 
Bankauskiene et al., 2020. Vocational Teachers' Opinions about the Already Acquired and Yet to be Improved Competences in the Context of the Fourth Industrial Revolution

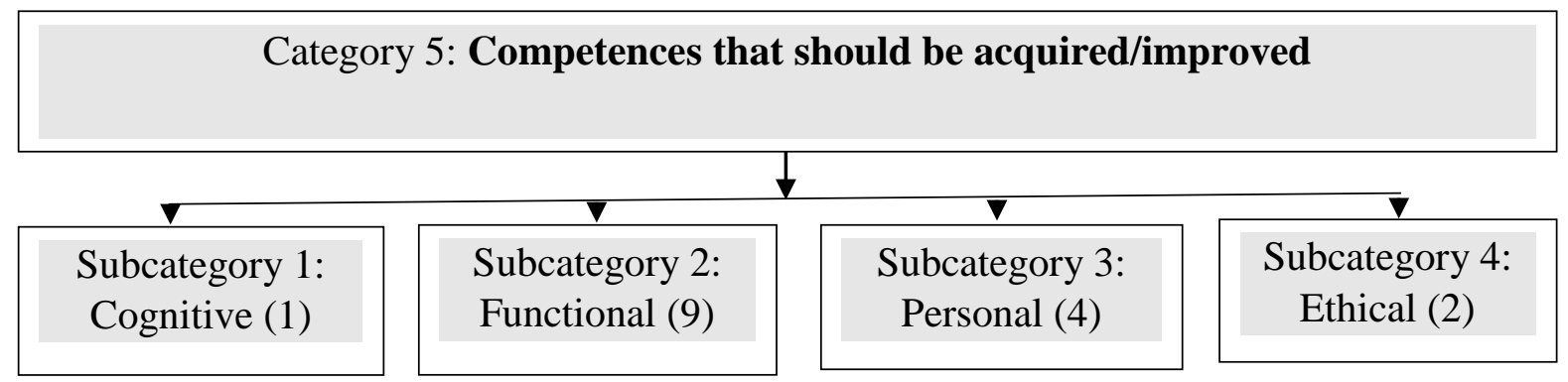

Figure 5 Subcategories of the category "Competences that should be acquired/improved", and the number of the supporting statements

In general, the round table discussions revealed that vocational teachers especially highly valued functional or activity competences. The teachers indicated that they had the highest number of such competences, but they would also like to improve them in the future. The teachers also associated these categories with challenges of the fourth industrial revolution.

Statements about vocational teachers' cognitive competences might raise some discussion. The teachers seemed to think that they had such competences as part of their theoretical preparation, and this emerged in their claims that they are capable of planning the subject content, creating educational environments, managing the learners, and widely applying information technologies. However, these functional competences are essentially impossible without cognitive competences. For this reason, the respondents, while especially emphasizing the functional competences, did not highlight cognitive competences.

The study also showed that the respondents emphasized personal competences. This indicates that vocational teachers especially value a person's education and ability to reflect, evaluate, and self-evaluate.

The respondents also emphasized the importance of ethical competences when presenting their opinions about the expression of personal and professional competences.

\section{Conclusions}

1. The groups of cognitive, functional, personal, and ethical competences described in Lithuanian documents that regulate teachers' qualification and vocational training are compatible with those described in the respective European documents.

2. The study of the opinions of teachers who worked in Kaunas city vocational training centers showed that:

- vocational teachers regarded the group of functional (activity) competences as most important for the quality of their work; 
- $\quad$ vocational teachers recognized the influence of the fourth industrial revolution and the peculiarities of the learners (generations " $Z$ " and "0") on changes in teachers' competences. According to vocational teachers, these factors had the greatest influence on the group of functional competences;

- the studied vocational teachers thought that they needed further development of their functional competences.

3. The interview with vocational teacher's highlighted all the competence groups described in the aforementioned documents. The group of functional competences was expressed the most, while the group of cognitive competences had the weakest expression.

\section{References}

Bankauskienè, N., \& Masaityte, R. (2018). Development of the Competencies of Technology Teachers in the Education Process by Applying Action Research. Society, Integration, Education, Volume V, 41-59. DOI: http://dx.doi.org/10.17770/sie2018vol1.3202

Bankauskienè, N., \& Masaityte, R. (2019). Application of Action Research in the Teaching/Learning Process for the Acquisition and Development of Competences: Attitudes of students - prospective teachers. Society, Integration, Education. DOI: http://dx.doi.org/10.17770/sie2019vol2.3794

Binklley, M., Erstad, O., Herman, J., Raizen, S., Ripley, M., Miller-Ricci, M., \& Rumble, M. (2012). Assessment and teaching of 21st century skills. In P. Griffin, B. McGaw, \& E. Care (Eds.), Defining twenty-first century skills. Dordrecht: Springer.

Boyatzis, R.E., \& Boyatzis, R.E. (2008). Competencies in the 21st century. DOI: http://doi.org/10.1108/02621710810840730

Caena, F. (2011). Education and Training 2020 Thematic Working Group "Professional Development of Teachers", Literature review Teachers' core competences: requirements and development. European Commission, April 2011.

Daukilas, S., Mičiulienè, R., Kovalčiukienè, K., \& Kasperiūnienė, J. (2016). Profesijos pedagogu veiklos turinys. Kaunas: ASU.

Fisk, P. (2017). Education 4.0 ... the future of learning will be dramatically different, in school and throughout life. Retrieved from http://www.thegeniusworks.com/ 2017/01/future-educationyoung-everyone-taught-together/

Grollmann, P. (2008). Professional competence as a benchmark for a European space of vocational education and training. Journal of European Industrial Training, 32(2/3), 138 - 156. DOI: http://doi.org/10.1108/03090590810861686

Harkins, A. (2008). Leapfrog Principles and Practices: Core Components of Education 3.0 and 4.0. Futures Research Quarterly draft, 8, 1-15.

Lietuvos Respublikos švietimo ir mokslo ministro ịsakymas „Dèl profesijos mokytojų kvalifikacijos tobulinimo nuostatu“. 2007-04-03 Nr. ISAK -591. Retrieved from https://e-seimas.lrs.lt/portal/legalAct/lt/TAD/TAIS.295381?jfwid=5w7avu7x7

Kunter, M., Klusmann, U., Baumert, J., Richter, D., Voss, T., \& Hachfeld, A. (2013). Professional Competence of Teachers: Effects on Instructional Quality and Student Development. Journal of Educational Psychology, 105(3), 805-820. DOI: http://doi.org/10.103 7/a0032583. 
Bankauskiene et al., 2020. Vocational Teachers' Opinions about the Already Acquired and Yet to be Improved Competences in the Context of the Fourth Industrial Revolution

Lietuvos Respublikos švietimo ir mokslo ministro įsakymas „Dèl mokytojų kompetencijos aprašo patvirtinimo“. 2007-01-15 Nr. ISAK-54. Retrieved from https://eseimas.lrs.lt/portal/legalAct/lt/TAD/TAIS.291726

Lietuvos respublikos švietimo ir mokslo ministro įsakymas „Dèl mokytojų (išskyrus trenerius) pareigybių aprašymo metodikos patvirtinimo“, $2018 \mathrm{~m}$. liepos $26 \mathrm{~d}$. Nr. V-674. Retrieved from https://eseimas.lrs.lt/portal/legalAct/lt/TAD/7ea5c44091d311e 8aa33fe 8f0fea665f?jfwid=124djr7i8l

Lietuvos Respublikos švietimo ir mokslo ministro įsakymas „Dèl reikalavimų mokytojo kvalifikacijos aprašo patvirtinimo“. 2014 m. rugpjūčio 29d. Nr. V-774. Retrieved from https://eseimas.lrs.lt/portal/legalActEditions/lt/TAD/7367f7d02fbf11e4b487eaabe28831 e8?faces-redirect=true

Marshall, C., \& Rossman, G.B. (2011). Primary Data Collection Methods Designing Qualitative Research (pp. 137-177). Los Angeles, CA: SAGE.

Oluwasola, A.J. (2014). Professional competence of technical teachers: A factor analysis of the training needs of technical college teachers. American Journal of Science and Technology, 2(1), 22-26.

Schwab, K. (2017). Ketvirtoji pramonès revoliucija. Vilnius: Vaga.

Švietimo sektoriaus ir biblioteku veiklos profesinis standartas. Retrieved from https://e seimas.lrs.lt/portal/legalAct/lt/TAD/494bed92ad8111e9b43db72f2154cfa0?jfwid=saqd0 kz19 